\title{
Incorporating multi-cohort old aspen and mixedwood dynamics into a long-term forest management plan
}

\author{
by Paul A. LeBlanc'
}

\begin{abstract}
The 2006-2026 Sustainable Forest Management Plan for Manitoba’s Duck Mountain Provincial Forest (DMPF) was required to model the Future Forest Condition 200 years from the present. This was a significant challenge for forest stands that were already old at the beginning of the planning and modelling horizon. In the DMPF, the majority of stands were currently old and near the end of the sampled yield curve. We incorporated aspen and aspen-mixedwood Permanent Sample Plot remeasurement data, aged up to 200 years old, into the yield curves. This extended the sampled volume-age data of the yield curves from 120 to 200 years old. The recent discovery of multi-cohort aspen and mixedwood stands was also incorporated into modelling the Future Forest Condition of the Sustainable Forest Management Plan. Multi-cohort stand dynamics replaced previous modelling assumptions of single-cohort, even-aged stands "breaking up" and suffering catastrophic loss (i.e., death age) where volume equals zero at stand ages 140 years or older. Modelling the multi-cohort stand dynamics resulted in a significantly different Future Forest Condition due to: maintenance of a continuous forest canopy over the entire landscape; higher modelled biodiversity in older stands due to multiple canopies, abundant snags, and coarse woody debris; and the avoidance of a large age class imbalance due to stands being available for harvest longer, but at a lower volume.
\end{abstract}

Keywords: aspen (Populus tremuloides), mixedwoods, gap-phase dynamics, single-cohort, multi-cohort, succession, future forest condition

\section{RÉSUMÉ}

Le plan d’aménagement forestier durable 2006 - 2026 de la forêt provinciale de Duck Mountain au Manitoba (DMPF) comprenait lobligation de modéliser les conditions forestières pour les prochaines 200 années. Il sagissait d’un défi majeur, considérant que les peuplements forestiers étaient déjà âgés au début de l'horizon de planification et de modélisation. Dans le cas de la forêt provinciale, la majorité des peuplements étaient déjà âgés et rendus presque au bout de la courbe de rendement documentée. Nous avons donc incorporé aux courbes de rendement les données du re-mesurage des parcelles- échantillons permanentes dans les tremblaies et les peuplements mixtes de tremble allant jusquà 200 ans. Il a ainsi été possible de documenter la portion de la courbe volume-âge entre 120 et 200 ans. La découverte récente de peuplements multicohortes de tremble et mixtes a également été prise en compte dans la modélisation des conditions forestières futures pour le plan d’aménagement forestier durable. La dynamique des peuplements multicohortes a donc remplacé les hypothèses antérieures de modélisation voulant que des peuplements équiennes à cohorte unique seffondrent et subissent des pertes catastrophiques (p. ex., âge de rupture) ramenant le volume à zéro à des âges de 140 ans et plus. La modélisation de la dynamique des peuplements multicohortes a donné des conditions forestières futures nettement différentes en raison : du maintien d'un couvert forestier continu sur lensemble du paysage forestier; d'une plus grande biodiversité modélisée dans les peuplements plus âgés due à la multiplication des strates, à labondance des chicots et de gros débris forestiers et à lévitement d'un déséquilibre important entre les classes dâges puisque les peuplements demeuraient exploitables sur une plus grande période, en dépit d’un volume moindre.

Mots clés : tremble (Populus tremuloides), peuplements mixtes, dynamique de la phase de rupture, cohorte unique, multicohortes, succession, condition forestière future

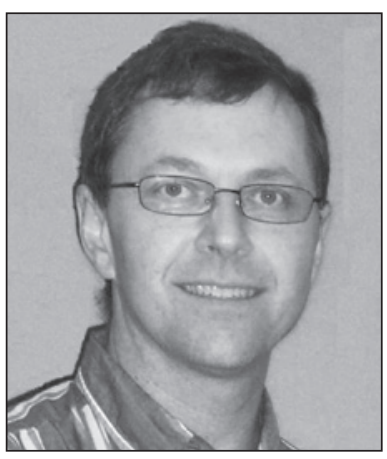

Paul A. LeBlanc

\section{Introduction}

Partway through the development of the Sustainable Forest Management Plan for the Duck Mountain Provincial Forest (DMPF) in Manitoba, an ecological discovery was made regarding multi-cohort aspen and mixedwood stands (Kenkel 2004). Later, Levac (2012) published a thesis using these data to quantify how evenaged, single-cohort aspen and aspen-spruce mixedwood stands change into multi-cohort aspen and mixedwood stands. This was a paradigm shift from the prevalent belief that hardwood and hardwood mixedwood stands are even-aged, single-cohorts (Perala 1990, Peterson and Peterson 1992).

The majority of forest stands in the DMPF are old stands, with inventory-estimated ages of 80 to 120 years old. Yield curves were constructed from Temporary Sample Plots (TSPs) aged 40 to 120 years old, in a stratified random sample. Modelling the Future Forest Condition of today's old stands 200 years into the future was a significant challenge as part of a Sustainable Forest Management Plan. Forest habitat elements (e.g., stand structure, snags, coarse woody debris, and carbon) were Modelled in addition to stand volume.

${ }^{1}$ LP Canada Ltd. - Swan Valley Forest Resources Division, PO Box 998, Swan River, MB. R0L 1Z0. E-mail: paul.leblanc@lpcorp.com. 
The macro overview of LP Canada Ltd. (2006) 20-Year Sustainable Forest Management Plan is shown in Fig. 1, and contains these elements:

1. ecosystem landbase,

2. ecosystem yield curves,

3. management goals, and

4. modelling and scenario planning.

Note that scenario planning specific to the DMPF is well described by Donnelly et al. 2009, and not discussed in this paper.

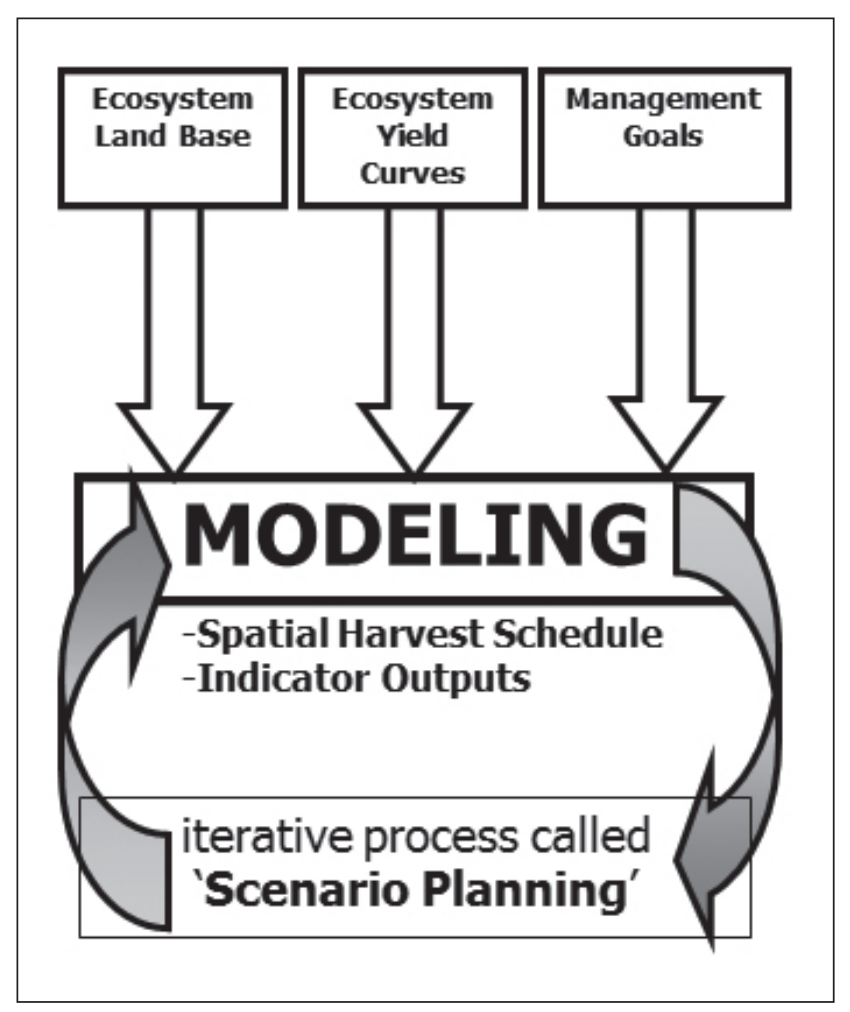

Fig. 1. Macro elements of LP's Sustainable Forest Management Plan.

\section{Methods}

\section{Study area}

The Duck Mountain Provincial Forest (DMPF) and the Riding Mountain National Park (RMNP) are in west-central Manitoba. Both forests are part of the Manitoba Escarpment, and are "island" forests surrounded by farm land (Fig. 2). Both areas are within the Boreal Plain ecozone and the MidBoreal Upland ecoregion. The fire history of this area is well described by Tardif (2004), and the current age structure is dominated by a large fire from the 1890s. The mixture of hardwood and softwood tree species is described by Hamel and Kenkel (2001).

\section{Ecosystem landbase}

The ecosystems of the DMPF were classified and mapped into ecosites by Arnup et al. (2006). Ecosites are a combination of soils (moisture and texture groups), tree canopies, and understory vegetation. Forested ecosites (Table 1) were aggregated into modelling strata (Table 1 and Fig. 3) within the forest management plan.

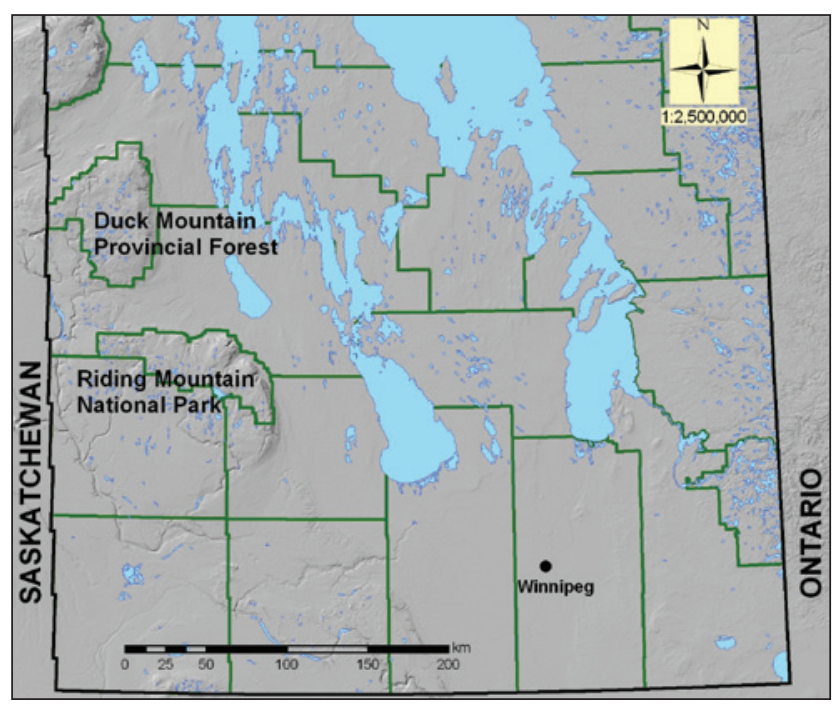

Fig. 2. Overview map of the Duck Mountain Provincial Forest and Riding Mountain National Park.

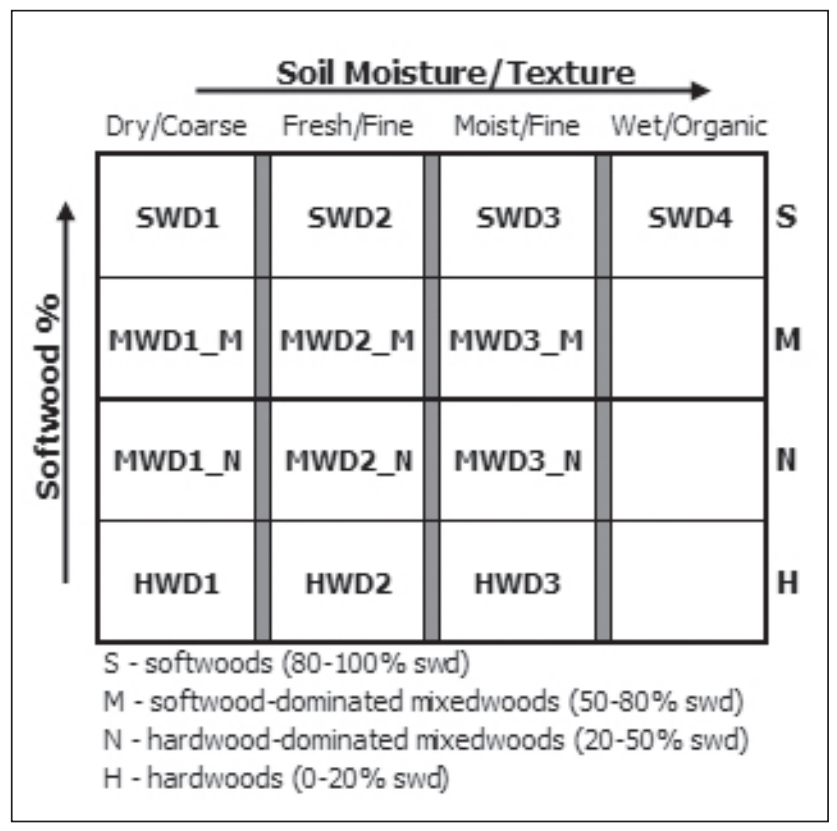

Fig. 3. Ecosystem landbase modelling strata, based on ecosites and percent softwood.

Note that succession or forest management can increase, decrease, or maintain the softwood percentage (i.e., can move up or down on Fig. 3 within a soil moisture/texture group). Forest management and natural disturbances, excepting glaciation, cannot change the soil moisture and texture (i.e., cannot move left or right on Fig. 3).

\section{Ecosystem yield curves - TSPs only}

Traditional volume-over-age yield curves were developed (The Forestry Corp 2004) from Temporary Sample Plots from the Duck Mountain Provincial Forest. These initial yield curves were single-cohort yield curves. The full range of sampled stands in the forest inventory ranged from ages 40 to 120 years 
Table 1. Forested ecosites of the Duck Mountain Provincial Forest (Arnup et al. 2006)

\begin{tabular}{|c|c|c|c|}
\hline EcoSERIES & Ecosite & Ecosite description $^{a}$ & $\begin{array}{c}\text { Ecosystem } \\
\text { modelling } \\
\text { strata }\end{array}$ \\
\hline \multirow{3}{*}{$\begin{array}{l}10 \\
\text { (dry moisture, } \\
\text { coarse soils) }\end{array}$} & 11 & TA-BA hardwood & HWD1 \\
\hline & 12 & TA-JP-Spruce mixedwood & MWD1_N \\
\hline & 13 & JP-BS feathermoss & SWD1 \\
\hline \multirow{4}{*}{$\begin{array}{l}20 \\
\text { (fresh moisture, } \\
\text { coarse soils) }\end{array}$} & 21 & WB mixedwood & MWD1_N \\
\hline & 22 & TA hardwood & HWD1 \\
\hline & 23 & TA-WS mixedwood & MWD1_N \\
\hline & 24 & JP-BS mixedwood & SWD1 \\
\hline \multirow{6}{*}{$\begin{array}{l}30 \\
\text { (average } \\
\text { moisture, clay } \\
\text { soils) }\end{array}$} & 31 & TA-BA hardwood / mixedwood & MWD2_N \\
\hline & 32 & TA-BA hardwood & HWD2 \\
\hline & 33 & TA-BA mixedwood & MWD2_N \\
\hline & 34 & WS-BF mixedwood & MWD2_M \\
\hline & 35 & JP-BS mixedwood & MWD2_M \\
\hline & 36 & $\begin{array}{l}\text { BS-JP-(WS-BF) Labrador tea- } \\
\text { feathermoss }\end{array}$ & SWD2 \\
\hline \multirow{3}{*}{$\begin{array}{l}40 \\
\text { (moist, sandy } \\
\text { soils) }\end{array}$} & 41 & TA-BA hardwood & HWD3 \\
\hline & 42 & WS-BF mixedwood & MWD3_M \\
\hline & 43 & BS-JP-feathermoss & SWD3 \\
\hline \multirow{3}{*}{$\begin{array}{l}\mathbf{5 0} \\
\text { (moist clay } \\
\text { soils) }\end{array}$} & 51 & TA-BA hardwood & HWD3 \\
\hline & 52 & TA-WS-JP mixedwood & MWD3_N \\
\hline & 53 & BS-feathermoss-Labrador-tea & SWD3 \\
\hline \multirow{4}{*}{$\begin{array}{l}60 \\
\text { (wet, organic } \\
\text { soils) }\end{array}$} & 61 & BS-(WS) -Lab tea - Fmoss - Sphagnum & SWD4 \\
\hline & 62 & BS-Alder-Herb Rich & non-merch ${ }^{\mathrm{b}}$ \\
\hline & 63 & TL-BS-Sedge & non-merch \\
\hline & 64 & BS-(JP)-Ericaceous-Sphagnum & non-merch ${ }^{\mathrm{b}}$ \\
\hline
\end{tabular}

a TA-trembling aspen (Populus tremuloides Michx.); BA-balsam poplar (Populus balsamifera L.); WB-white birch (Betula papyrifera Marsh.); JP-jack pine (Pinus banksiana Lamb); BS-black spruce (Picea mariana [Mill.] BSP); WS-white spruce (Picea glauca [Moench] Voss); TL-tamarack/larch (Larix laricina [Du Roi] K. Koch); BF-balsam fir (Abies balsamea [L.] Mill.).

${ }^{\mathrm{b}}$ Note that non-merchantable forested ecosites 62 to 64 were not used as modelling strata.

old. Therefore, only the sampled data range was plotted on the yield curve (Fig. 4a). Outside the range of data, a modelling assumption of death age was applied at 140 years for aspen stands. Death age is a concept used in Manitoba (Manitoba Conservation 2004) and other Canadian provinces. It assumes stand volume declines until stand volume is zero (Fig. 4b). The SFMP required a 200-year modelling run; therefore, yield curves were extended out to 400 years to allow stands that were old at the beginning of the modelling run to age an additional 200 years. The 400-year yield curve covers the phases of regeneration, growth, decline, followed by death age for three rotations (Fig. 4c).
Ecosystem yield curves - PSPs and TSPs In 1946, the Dominion Forest Service established 1484 Permanent Sample Plots (PSPs) in Riding Mountain, Manitoba. Stand ages of the original 1946 PSPs varied from 10 to 150 years old. These data existed only as paper tally sheets until 2001 when LP Canada Ltd. and the Northern Forestry Centre cooperatively entered, cleaned, and screened these data into a relational database. PSPs were remeasured in $1951(n=529), 1956(n=1403)$, $1961(n=76)$, and $1966(n=1369)$ and were further supplemented by 286 PSP remeasurements funded by LP Canada in 2002. LP Canada sub-sampled $10 \%$ of the understory trees (i.e., trees $<9.0 \mathrm{~cm} \mathrm{DBH}$ ) in each PSP. Kenkel (2004) remeasured the remaining $90 \%$ of understory trees, due to their importance in forming additional canopy cohorts. These efforts yielded a total of 55 years of remeasurement PSP data, with stands as old as 205 years, at the last remeasurement in 2002. The quality and amount of data in the Riding Mountain National Park PSPs represent the best available in Canada (Table 2).

The Riding Mountain PSP data were originally stratified by ecosite (Arnup et al. 2006). Later, similar ecosites were aggregated into pure aspen (with no white spruce seed source), aspen (>80\% aspen), and mixedwood groups by Kenkel (2004). Actual trajectories were compared to Modelled trajectories. General successional trends (Fig. 5) were developed by Kenkel (2004).

The single-cohort yield curves from the Duck Mountain Provincial Forest ((Fig. 6a and 6d) were very similar to Kenkel's (2004) multi-cohort yield curves (Fig. 6b and 6e). The HWD2 aspen stratum was a near-perfect fit from ages 40 to 120 years old (Fig. 6b), while the aspen mixedwood stratum was reasonably similar (Fig. 6e).

Kenkel's (2004) pure hardwood (Fig. 5a) and $>80 \%$ aspen (Fig. 5b) general successional trend models are identical, up to age 120 years old. Therefore, pure hardwood and $>80 \%$ aspen models were combined in order to have only one aspen cover type, which conformed to the provincial cover type requirements. The final yield curves for HWD2 (Fig. 6c) and MWD2_N strata (Fig. 6f) were from combined data, both single-cohort data from the DMFP, and multi-cohort PSP data from RMNP.

Several forest mensurationists assured the modelling team that there is currently no known mathematical function robust enough to rise and fall multiple times as the stands grow, break up, recover volume due gap-phase regeneration, then open and close the canopy multiple times (Fig. 6). Since fitting a function to these data was not possible, the multi-cohort general succession trends were spliced onto the single-cohort yield curves.

The long-term plan biodiversity and modelling teams reviewed the multi-cohort concept, successional trends, and the 
Table 2. Number of measurements per PSP for the Riding Mountain National Park data

\begin{tabular}{cc}
\hline $\begin{array}{c}\text { Number of measurements } \\
\text { per PSP }\end{array}$ & Number of PSPs \\
\hline 1 & 33 \\
2 & 64 \\
3 & 647 \\
4 & 657 \\
5 & 83 \\
Total & 1484 \\
\hline
\end{tabular}

data supporting multi-cohort dynamics. They also noted that both areas were within the Mid-Boreal Upland ecoregion, and that the two forests are within $100 \mathrm{~km}$ of each other. All these factors provided the modelling team with the confidence to unanimously agree to incorporate multi-cohort stand dynamics into the yield curves for all ecosystem strata (Fig. 3) used in the Sustainable Forest Management Plan.

Forest habitat element curves (Van Damme et al. 2005) were generated for all 13 ecosystem strata (Fig. 3). Habitat element curves incorporated stand-level structural and habitat element attributes, including stand structure, snags, coarse woody debris, and shrub cover. Furthermore, carbon yield curves were developed by Johnston (2005) for all 13 ecosystem strata (Fig. 3 ). These carbon yield curves quantified carbon pools in the soil, stem and non-stem biomass, which allowed a 200-year carbon budget to be generated with each modelling run.

\section{Management goals}

The management goals for the SFMP were based on Criterion and Indicators (CCFM 2003), with modifications from extensive consultation and workshops with stakeholders, First Nations, conservation and environmental organizations, as well as the public. SFMP management goals were kept consistent for the final modelling runs described in this article.

\section{SFMP Objective 1: Maintain ecosystem health and function}

1.1 Maintain the representation of the current range of ecosystem groups and associated forest species composition;

1.2 Maintain the existing range of forest structure conditions over the long term;

1.3 Maintain a functional landscape pattern of forest cover and habitat types consistent with the principles of natural disturbance pattern emulation;

1.4 Conserve ecosystem condition and productivity by limiting road length, duration and density;

1.5 Provide additional, fine filter, protection of rare ecosites and areas with high levels of biodiversity; 1.6 Maintain forest productivity by ensuring prompt forest renewal; and

1.7 Maintain forest health.

\section{SFMP Objective 2: To provide goods and services for present and future generations}

Goods and services include, but are not limited to, wildlife habitat, water yield, carbon stocks, and timber.

2.1 Maintain the representation of the current range of wildlife habitat associations;

2.2 Limit disturbances within sub basins to acceptable levels as defined by the Department of Fisheries and Oceans;

2.3 Maintenance of forest carbon stocks;

2.4 Include both public consultation and scientific research in the forest management planning process; and

2.5 Maintain stable harvest levels over time. 


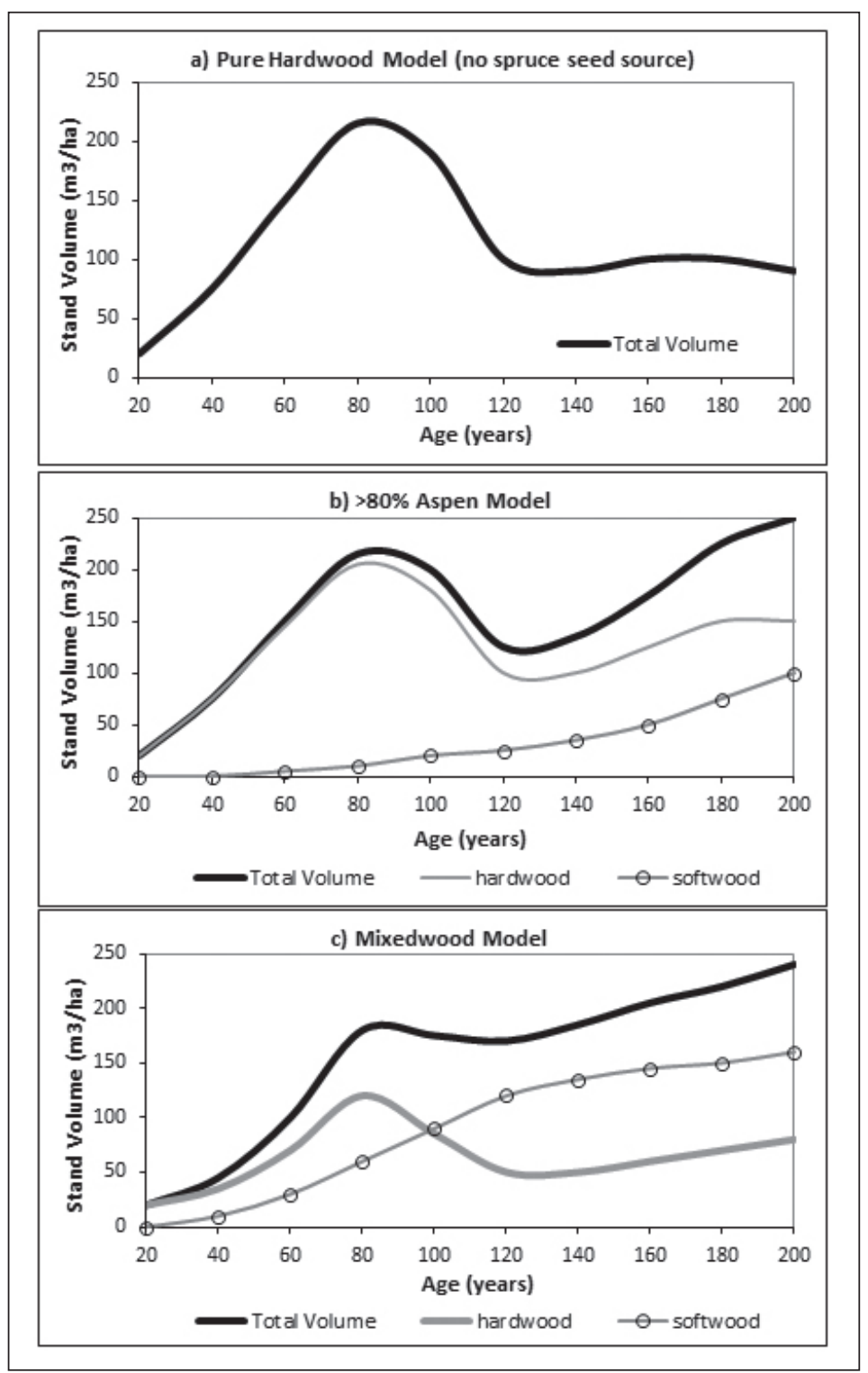

Fig. 5. General successional trends from the Riding Mountain PSP data (Kenkel 2004): a) pure aspen (no spruce seed source); b) >80 aspen; and c) aspen-spruce mixedwood.

\section{Results}

\section{Successional trend results}

Kenkel's (2004) analysis of the Riding Mountain PSP data showed clear evidence of gap-phase dynamics that renewed and maintained both aspen and mixedwood multi-cohort stand canopies (Fig. 5). Pure aspen, older forests maintained themselves at lower than maximum volume. In mixedwoods, forests canopies gradually increased in conifer associated with small openings and increased in aspen occurring in larger openings. Average tree age varied more as time since disturbance lengthened, and stand volume gradually rose and fell in association with canopy gaps that opened and closed.

The general characteristics of single and multicohort stand canopy stands (Table 3 ) were populated from Kenkel's (2004) analysis, as well as the temporary sample plot data from the DMPF forest inventory (The Forestry Corp 2003). Example photographs of single and multi-cohort stands are shown in Fig. 7.

Modelling results - comparison of single and multicohort

The spatial model Patchworks (Spatial Planning Systems 2006) was used for 200-year modelling runs on the same ecological landbase, and the same management objectives, but for two groups of yield curves, single cohort and multi-cohort yield curves. The modelling results on the Future Forest Conditions using single-cohort yield curves were compared to the results of using multi-cohort yield curves.

Growing stock (i.e., volume of all tree species across the entire DMPF) was significantly higher in the long term (Fig. 8a) when multi-cohort stand dynamics were accounted for. Stand-level mortality volume was dramatically lower in the long term (Fig. 8b), and the amount of forest roads needing to be built to access the same volume of wood was also significantly lower (Fig. 8c) for multi-cohort stand dynamics. The age class structure modelling results show that more old forest can be retained in the DMPF when multi-cohort stand dynamics were accounted for (Fig. 8d).

Table 3. General characteristics of single and multi-cohort stands in the DMPF and RMNP

\begin{tabular}{|c|c|c|}
\hline & Single Cohort & Multi-cohort \\
\hline \multirow[t]{3}{*}{ Age } & younger ( 0 to 100 years old) & older (100 to 200 years old) \\
\hline & $\begin{array}{l}\text { narrow age range } \\
\text { tree age }=\text { stand age }=\text { time since disturbance }\end{array}$ & $\begin{array}{l}\text { wide range of ages (often oldest trees cannot be } \\
\text { aged due to decay) }\end{array}$ \\
\hline & & tree age $\neq$ stand age $\neq$ time since disturbance \\
\hline Diameter & consistent, narrow range of diameters & $\begin{array}{l}\text { wide range of diameters, often the largest } \mathrm{DBH} \\
\text { aspen have significant stem rot }\end{array}$ \\
\hline Height & relatively consistent heights & discernible canopies of differing heights \\
\hline Density & fully occupied site, near maximum density & below average density due to canopy gaps \\
\hline Volume & higher volume, $\sim 200 \mathrm{~m}^{3} /$ ha peak volume & $\begin{array}{l}\text { lower volume, } \sim 120-150 \mathrm{~m}^{3} / \text { ha fluctuating volume } \\
\text { due to canopy gaps opening and closing }\end{array}$ \\
\hline Canopy & single canopy & multiple canopies \\
\hline Dominant disturbance & $\begin{array}{l}\text { stand-replacing disturbances such as fire, harvesting, } \\
\text { massive wind throw }\end{array}$ & $\begin{array}{l}\text { sub-stand disturbances such as single tree decay, } \\
\text { minor wind throw, limited insect attack }\end{array}$ \\
\hline
\end{tabular}




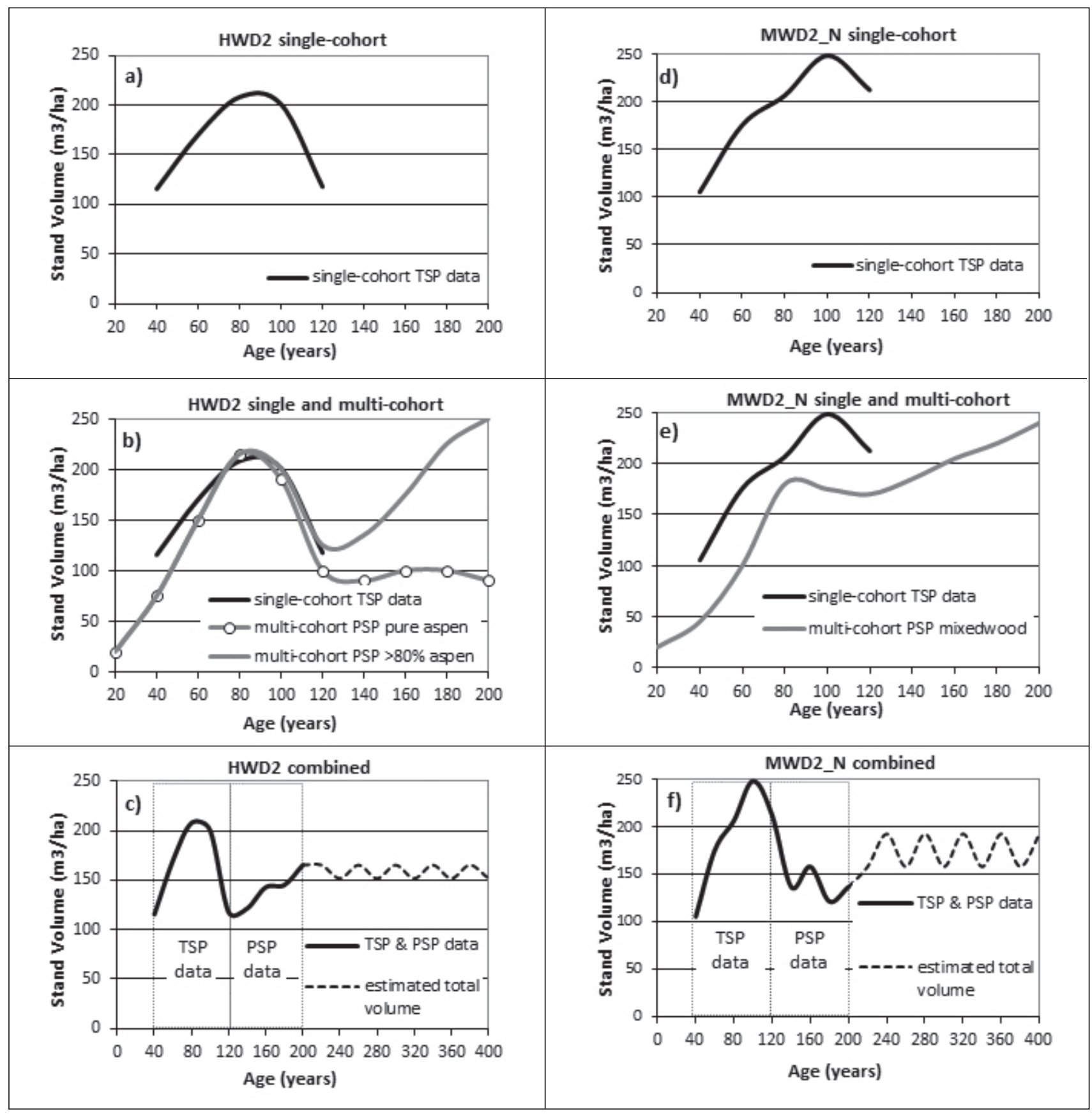

Fig. 6. Total volume over age curves for: hardwood on average moisture clay (HWD2 stratum) and hardwood-spruce mixedwood on average moisture clay (MWD2_N stratum), showing: a and d) sampled volumes of single-cohort data (ages 40 to 120 years old); b and e) overlay of single and multi-cohort data (ages 20 to 200 years old); and c and f) 400 year yield curve, including estimated volumes from ages 200 to 400 years.

\section{Discussion}

Multi-cohort stand dynamics replaced previous modelling assumptions of even-aged stands "breaking up" and suffering catastrophic loss (i.e., modelling death age). Extrapolation of declining stand volumes to a volume of zero was an erroneous assumption. Instead, older aspen and aspen-spruce mixedwood PSP data were found to maintain multiple cohorts, but at a lower stand volume. The multi-cohort nature of older aspen stands is not an isolated phenomenon unique to Manitoba. Multi-cohort aspen persisting long past rotation age has also been found in Alberta (Cumming et al. 2000, Huang et al. 2007, Huang 2012) and Quebec (Bergeron 2002, Harvey et al. 2002, Namroud et al. 2005).
Are all the stands in the Duck Mountain Provincial Forest single-cohort as originally assumed, or are they multi-cohort stands? We were surprised to discover that the majority of older stands in the DMPF actually were multi-cohort stands, and were older than we realized (Cumming et al. 2000, Tardif 2004). Younger stands in the DMPF were single-cohort, but often transition into multi-cohort stands after stand breakup creates gaps, and gap-phase regeneration forms a second cohort.

The significance of utilizing multi-cohort stand dynamics instead of assuming all stands are single-cohort is considerable. Older stand volumes begin to decline relatively rapidly. Under the assumption that all stands are single-cohort, unharvested older stands continue to decline, hit death age, lose their forest 


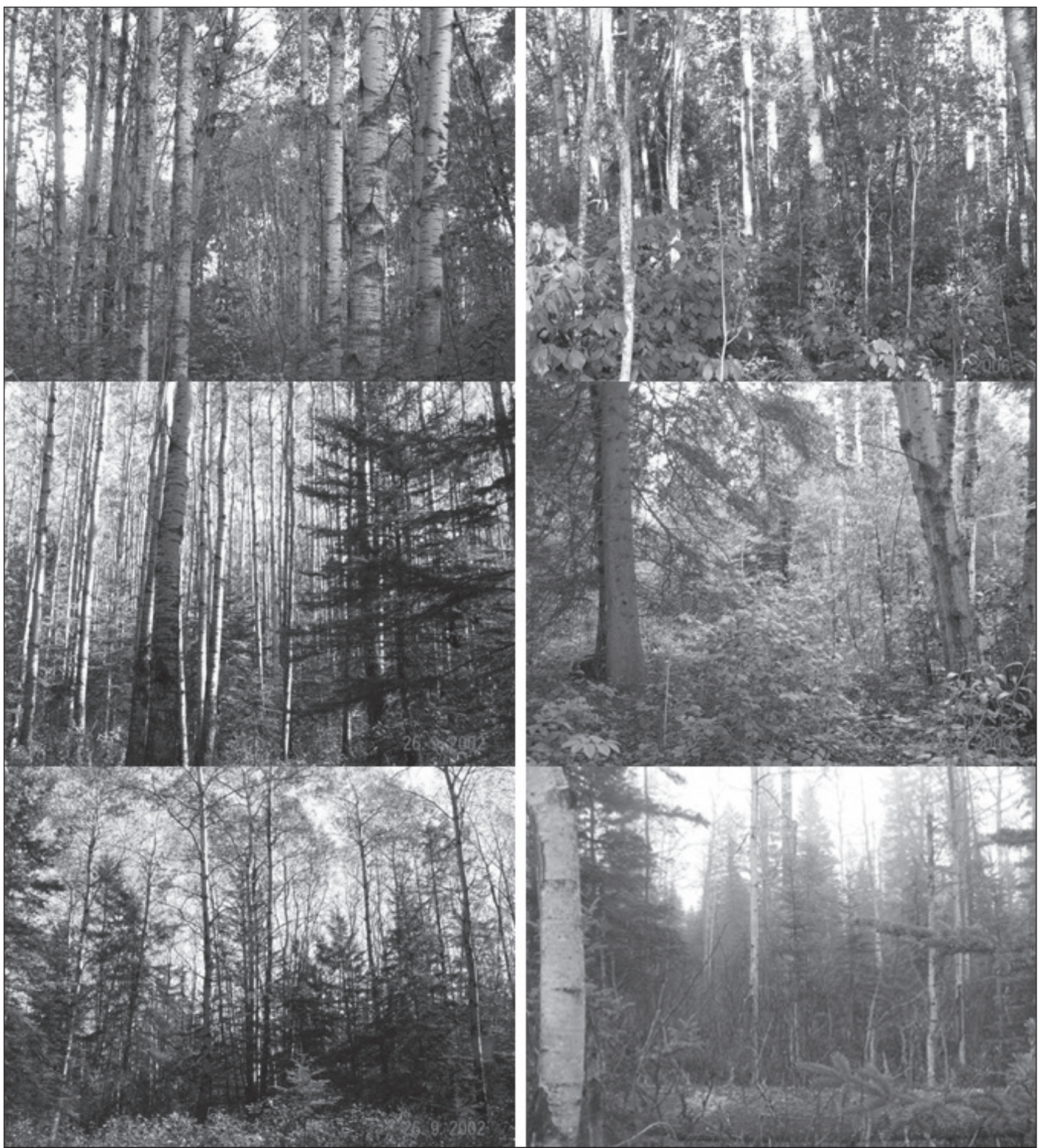

Fig. 7. Examples of: single-cohort stands on the left, and multi-cohort stands on the right - pure aspen, aspen, and aspen mixedwoods (top to bottom, respectively).

canopy, regenerate, then become a merchantable stand again. However, there is a 60-year period when these stands are assumed to be not available for harvest, due to very low volumes. In contrast, the multi-cohort stand dynamics retain a forest canopy after breakup begins, but at a lower volume. These stands have sufficient volume to warrant harvesting, and avoid the 60year harvest scheduling gap (Fig. 9).

Harvest scheduling, under the single-cohort yield curves, "chases" the declining volume stands before they reach 120 years old, in order to avoid the assumed loss of all stand volume.
Spatially, chasing the declining stands results in a very fragmented harvest schedule. An additional negative consequence is a grossly excessive amount of forest road to access scattered stands that are assumed to have an impending volume of zero.

If death age did exist, and stand volumes rapidly declined to zero, then there would be a catastrophic canopy collapse resulting in no forest canopy. All of the stand's volume would be either snags or coarse woody debris on the forest floor. Catastrophic, stand-replacing natural events such as blowdown or fire could have some of the characteristics of a death age stand. However, 

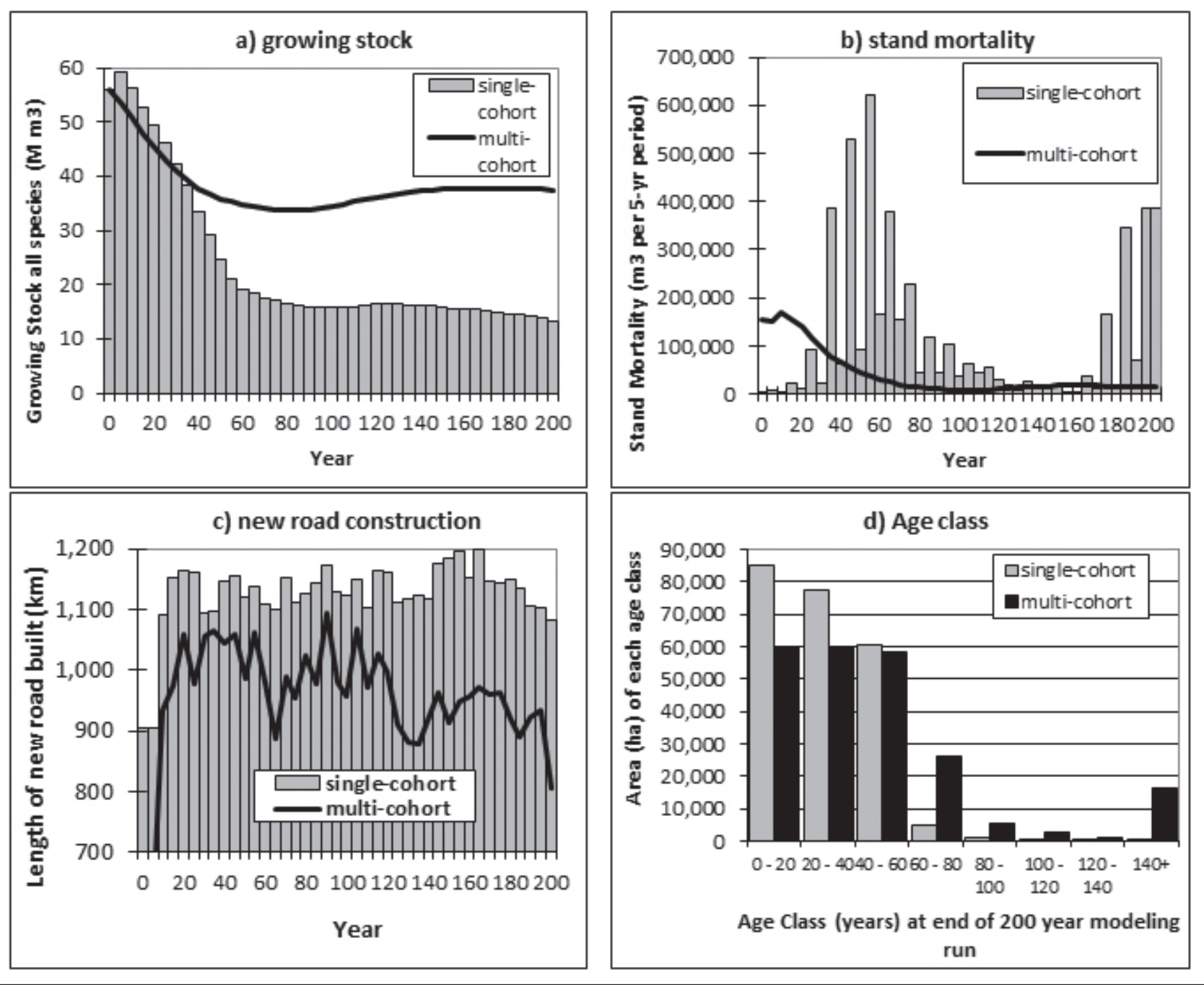

Fig. 8. Comparison of modelling output for both single and multi-cohort yield curves in the DMPF for: a) growing stock; b] stand mortality; c) new road construction; and d) age class structure.

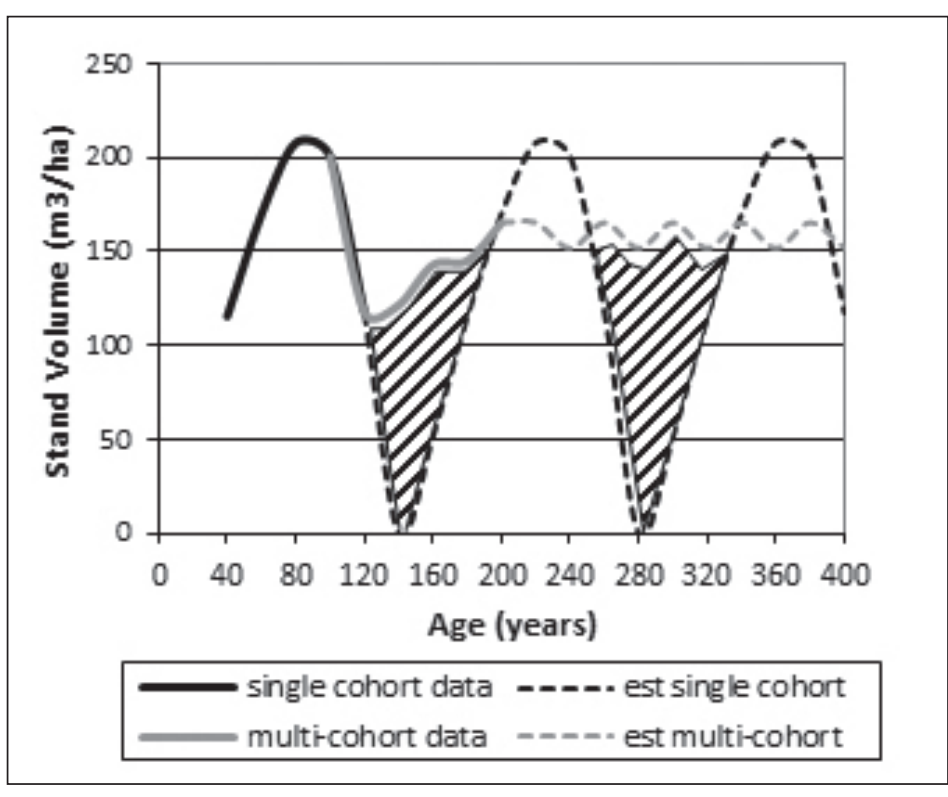

Fig. 9. An overlay of single-cohort and multi-cohort yield curves (HWD2 stratum), emphasizing (striped area) the significant difference between sampled (solid lines) and extrapolated (dashed lines) stand volumes. the timing of the natural event would be random rather than at a defined age, such as 140 years. Also, death age assumes every stand in the forest will always undergo replacement at a defined age. We found no evidence of recent or past death age stands in the 2002 forest lands inventory, or in the previous 1982 forest resources inventory of the DMPF. Death age is an unfounded assumption, and a modelling shortcut to be avoided.

The Sustainable Forest Management Plan had a significantly different Future Forest Condition, due to acknowledging the existence of multi-cohort stand dynamics. A continuous forest canopy was maintained over the entire landscape. Higher biodiversity was modelled in older stands, due to multiple canopies, abundant snags, and coarse woody debris. An assumed large age class imbalance was avoided, due to a longer harvest window, but at a much lower volume. Lastly, a greater amount of old forest was retained, since old forest reserves, buffers, and unharvested areas were allowed to get older, instead of meeting death age and these stands artificially being set to zero years old in the modelling landbase. 
Artificially resetting old stands aged 140 years old back to a stand age of zero results in a modelling landbase where no aspen or mixedwood stands can ever exceed 140 and 160 years old, respectively. This results in a gross under-estimation of old forest. The Duck Mountain Provincial Forest currently contains over 21000 ha, or $6 \%$ of the gross landbase, that is older than 140 years old as mapped by Tardif's (2004) time-since-last-fire research.

After a stand-replacing event occurs (e.g., harvesting or fire) in the Duck Mountain, aspen or mixedwood stands begin as even-aged, single-cohort stands. However, if left undisturbed from a stand-replacing event, these stands transition into uneven-aged, multi-cohort stands during the period where breakup begins, and gap-phase regeneration fills in stand gaps. Multi-cohort stands appear to be in a stable state, and maintain themselves. Of course, a stand-replacing event would reset stands back to an even-aged single-cohort stand.

\section{Conclusions}

Incorporating multi-cohort stand dynamics into the ecological yield curves had a very profound effect on the Future Forest Condition of the Sustainable Forest Management Plan for the Duck Mountain Provincial Forest. Higher biodiversity was modelled in older stands, due to multiple canopies, abundant snags, and coarse woody debris. Other benefits included greater retention of growing stock, significantly less stand-level mortality, more even wood flows, and the potential for more efficient spatial harvest layout, which lead to significantly less road building and road decommissioning.

We as foresters have previously missed the significance of small, unmerchantable aspen attempting to struggle into a second forest canopy. Typically, unmerchantable trees are not even tallied on temporary plots, while on permanent plots only a small sample of unmerchantable trees are measured. While aspen is a shade-intolerant, pioneer species, and dependent upon disturbance for regeneration, older aspen and aspen-spruce stands can regenerate due to the gap-phase regeneration allowing a new cohort of aspen to form a second forest canopy. These multi-cohort stands may be in an ecological climax state at stand ages beyond 200 years old. Future remeasurements on the Riding Mountain permanent plots will provide additional answers and insights to the stand dynamics of very old aspen and aspen-spruce mixedwoods.

\section{Acknowledgements}

The 20-year Sustainable Forest Management Plan contributors in the biodiversity team and modelling team included: Laird Van Damme (KBM Consulting), Margaret Donnelly (Donnelly Ecological Consulting Services Inc.), Dr. Norm Kenkel (University of Manitoba), Donna Kopecky (LP Canada Ltd.), Tom Moore (Spatial Planning Systems), and Dr. Rob Rempel (Centre for Northern Forest Ecosystem Research).

\section{References}

Arnup, R.A., P.A. LeBlanc and G. Becker. 2006. Field guide to Ecosites of the Mid-Boreal Upland Ecoregion of Manitoba. Unpublished. LP Canada Ltd. Swan River, MB.

Bergeron, Y. 2002. Species and stand dynamics in the mixed woods of Quebec's southern boreal forest. Ecology 81 (6): 1500-1516.

[CCFM] Canadian Council of Forest Ministers. 2003. Defining sustainable forest management in Canada: criteria and indicators 2003. Technical Supplement 1. Detailed indicator descriptions. 56 p. Available at http://ccfm.org/pdf/CI2003_tech_sup_1.pdf [Accessed 18 February 2013].
Cumming, S.G., F.K.A. Schmiegelow and P.J. Burton. 2000. Gap dynamics in boreal aspen stands: Is the forest older than we think? Ecological Applications 10 (3): 744-759.

Donnelly, M., L. Van Damme, T. Moore, R.S. Rempel and P.A. LeBlanc. 2009. Scenario planning and operational practices within a sustainable forest management plan. In S. Gauthier, M.-A. Vaillancourt, A. Leduc, L. De Grandpré, D. Kneeshaw, H. Morin, P. Drapeau and Y. Bergeron (eds.). Ecosystem Management in the Boreal Forest. pp. 423-448. Presses de l'Université du Québec, Québec, QC.

Hamel, C. and N. Kenkel. 2001. Structure and dynamics of boreal forest stands in the Duck Mountains, Manitoba. Final project report 2001-4, Sustainable Forest Management Network. University of Alberta, Edmonton, AB. 49 p.

Harvey, B., A. Leduc, S. Gauthier and Y. Bergeron. 2002. Standlandscape integration in natural disturbance-based management of the southern boreal forest. Forest Ecology and Management 155: 369-385. Huang, S. 2012. Modeling the long-term productivity and successional pathways of aspen in Alberta. Oral presentation at the Boreal Mixedwoods 2012 Conference. June 17-20, 2012. Delta Edmonton South, Edmonton, $\mathrm{AB}$.

Huang, S., S. Meng, Y. Yang, and V. Lieffers. 2007. Modeling the species composition dynamics of aspen in boreal mixedwoods. Oral presentation at IUFRO conference: Complex stand structures and associated dynamics. July 29-August 2, 2007, Sault Ste. Marie, ON.

Johnston, M. 2005. Carbon yield curves for Duck and Porcupine Provincial Forests of Manitoba. Saskatchewan Research Council. Saskatoon, SK. 13 p. LP Canada Ltd. Swan River, MB.

Kenkel, N.C. 2004. Successional trends based on the Riding Mountain data (unpublished). LP Canada Ltd. Swan River, MB.

Levac, J. 2012. Long-term stand dynamics of the boreal mixedwood forests of west central Manitoba. M.Sc. thesis. Department of Biology. University of Manitoba, Winnipeg, MB.

LP Canada Ltd. 2006. 20-year Sustainable Forest Management Plan (2006-2026). LP Canada Ltd., Swan Valley Forest Resources Division. Swan River, MB. Available at http://www.swanvalleyforest.ca/planning/ LongTermPlan.html [Accessed 5 December 2012].

Manitoba Conservation. 2004. Wood supply analysis report for forest management unit 13 and 14. Forestry Branch, Manitoba Conservation. 200 Saulteaux Crescent, Winnipeg, MB. 39 p.

Namroud, M.-C., F. Tremblay and Y. Bergeron. 2005. Temporal variation in quaking aspen (Populus tremuloides) genetic and clonal structures in the mixedwood boreal forest of eastern Canada. Ecoscience 12(1): 82-91.

Perala, D.A. 1990. Populus tremuloides Michx. Quaking aspen. In R.M. Burns and B.H. Honkala (eds.). Silvics of North America, Volume 2. pp. 555-569. Hardwoods. USDA Forest Service. Agricultural Handbook 654. Available from http://na.fs.fed.us/pubs/silvics_manual/ table_of_contents.shtm [Accessed 7 February 2013].

Peterson, E.B. and N.M. Peterson. 1992. Ecology, management, and use of aspen and balsam poplar in the prairie provinces. Special report 1. Forestry Canada, Northwest Region, Northern Forestry Center, Edmonton, AB. 252 p.

Spatial Planning Systems. 2006. Patchworks spatial planning software. Available at http://www.spatial.ca/ [Accessed 20 February 2013].

Tardif, J.C. 2004. Fire history in the Duck Mountain Provincial Forest, western Manitoba. Project reports 2003/2004, Sustainable Forest Management Network. University of Alberta, Edmonton, AB. 29 p.

The Forestry Corp. 2003. Ecosystem field sampling program. Volume sampling summary: field seasons 2000, 2001 and 2002 stand and stock tables for FMU 13 and FMU 14. Prepared for Louisiana-Pacific Canada Ltd., Swan River, MB. March 26, 2003. 100 p.

The Forestry Corp. 2004. Natural stand yield curves. Summary report prepared for: Louisiana-Pacific Canada Ltd., Swan River, MB. May 26, $2004.30 \mathrm{p}$.

Van Damme, L. K. Hautala and A. Taylor. 2005. Habitat element curves: creation and validation. KBM Forestry Consultants, Thunder Bay, ON. 31 p. 